\title{
PERANAN KOMUNIKASI BAHASA DALAM PEMBELAJARAN MATEMATIKA PADA SISWA KELAS V SDN KERATON 3 MARTAPURA
}

\author{
Fajarika Ramadania, Noor Indah Wulandari, Nahlini \\ STKIP PGRI Banjarmasin, STKIP PGRI Banjarmasin, SDN Keraton 3 Martapura \\ Framadania@stkipbjm.ac.id, ndah_wulandari@stkipbjm.ac.id, nahlini89@gmail.com
}

\begin{abstract}
Abstrak: Bahasa dan matematika merupakan ilmu yang berbeda dan masing-masing memiliki cakupan yang berdiri sendiri. Bahasa memiliki fungsi untuk menyatakan ide, pikiran, gagasan, atau perasaan seseorang kepada orang lain. Sedangkan matematika adalah ilmu pasti yang berdasarkan pada kegiatan penelusuran pola dan hubungan. Fungsi inilah yang digunakan oleh guru untuk memahamkan peserta didik dalam setiap pembelajaran, termasuk matematika. Dalam bilangan bulat terdapat dua jenis bilangan yaitu positif dan negatif yang dapat dioperasikan dalam penjumlahan, pengurangan, perkalian, dan pembagian. Namun, dalam penelitian ini hanya menjelaskan mengenai penjumlahan dan pengurangan saja. Penelitian ini bertujuan untuk mengetahui tentang pengaruh kemampuan komunikasi bahasa dalam pembelajaran matematika terhadap hasil belajar matematika peserta didik siswa kelas V SDN Keraton 3 Martapura. Metode penelitian yang digunakan adalah survei dan eksperimen dengan populasi peserta didik kelas $\mathrm{V}$ SDN Keraton 3 Martapura sebanyak 27 orang. Instrumen yang digunakan adalah instrumen kemampuan komunikasi bahasa dan instrumen prestasi belajar matematika. Hasil penelitian menunjukkan bahwa terdapat pengaruh positif dan signifikan kemampuan komunikasi bahasa dalam pembelajaran matematika terhadap prestasi belajar matematika. Alternatif pendekatan yang digunakan dalam pembelajaran matematika adalah logika deduktif dan logika induktif. Logika induktif erat kaitannya dengan penarikan kesimpulan kasus individual khusus nyata menjadi kesimpulan yang bersifat umum. Sedangkan logika deduktif adalah kegiatan berpikir sebaliknya dari penalaran induktif. Deduktif adalah cara berpikir di mana dari pernyataan yang bersifat umum ditarik kesimpulan yang bersifat khusus.
\end{abstract}

Kata Kunci: komunikasi, logika, bahasa, pembelajaran, matematika

Menurut (Musfiqon, 2012, hal.16) komunikasi merupakan kegiatan rutin setiap interaksi antara dua orang atau lebih. Bahasa merupakan alat komunikasi yang penting bagi semua orang agar pihak-pihak yang berada pada ruang lingkup komunikasi itu menjadi mengerti apa yang disampaikan dan dibicarakan. Komunikasi ilmiah mensyaratkan bentuk komunikasi yang sangat berbeda dengan komunikasi estetik. Komunikasi ilmiah bertujuan untuk menyampaikan informasi yang berupa pengetahuan. Agar komunikasi ilmiah ini berjalan dengan baik, maka bahasa yang digunakan harus bebas dari unsur emotif. Komunikasi ilmiah harus bersifat reproduktif, artinya bila si pembicara menyampaikan informasi berupa $\mathrm{X}$, maka si penerima informasi juga menerima informasi X pula.

Untuk mampu mengomunikasikan pengetahuan atau jalan pikiran yang jelas maka seseorang harus menguasai tata bahasa dengan baik. Penguasaan tata bahasa yang baik merupakan syarat mutlak bagi suatu 
komunikasi ilmiah yang benar. Rendahnya mutu pendidikan mungkin karena penyajian pembelajaran disajikan masih dalam bentuk yang kurang menarik, sehingga terkesan menakutkan, sulit, dan tidak mudah dicapai sehingga siswa sering tidak menguasai konsep dasar yang terkandung dalam materi pelajaran Matematika yang dapat mengakibatkan kesalahan fatal terhadap keberhasilan belajar siswa sehingga hasil belajar siswa menjadi rendah.

Salah satu masalah penting dalam pembelajaran matematika saat ini adalah pentingnya pengembangan kemampuan komunikasi matematika siswa. Untuk menghindari kesalahan fatal dalam belajar matematika diperlukan penalaran yang merupakan suatu proses berpikir yang membuahkan pengetahuan. Agar pengetahuan yang dihasilkan penalaran itu mempunyai dasar kebenaran maka proses berpikir itu harus dilakukan suatu cara tertentu. Suatu penarikan kesimpulan baru dianggap valid kalau proses penarikan kesimpulan tersebut disebut logika, dimana logika dapat didefinisikan sebagai pengkajian untuk berpikir secara benar.

Terdapat beberapa macam penarikan kesimpulan, namun untuk sesuai dengan tujuan yang memuaskan diri kepada penalaran ilmiah, kita akan melakukan penelaahan secara saksama hanya terhadap dua jenis cara penarikan yaitu logika induktif dan deduktif. Logika induktif erat kaitannya dengan penarikan kesimpulan kasus individual nyata menjadi kesimpulan yang bersifat umum. Di pihak lain, logika deduktif membantu kita dalam menarik kesimpulan dari hal-hal yang bersifat umum menjadi kasus yang bersifat individual (khusus).

Pada operasi bilangan bulat dan pecahan, masih banyak peserta didik di SDN
Keraton 3 Martapura yang kesulitan dalam menyelesaikan persoalan penjumlahan dan pengurangan. Hal ini terjadi dikarenakan mereka mengoperasikan bilangan yang berbeda jenis, yaitu bilangan positif dan negatif. Penggunaan garis bilangan bisa menjadi solusi, akan tetapi tidak mungkin menggunakan garis tersebut apabila digunakan lebih dari sepuluh. Maka dari itu guru memberikan solusi berupa penggunaan bahasa untuk memberikan makna pada operasi penjumlahan dan pengurangan sehingga peserta didik bisa dengan mudah menyelesaikan persoalan operasi tersebut.

Berkaca dari pernyataan di atas, penggunaan bahasa merupakan salah satu upaya yang bisa dilakukan untuk memecahkan persoalan yang tidak bisa dilakukan melalui garis bilangan. Penggunaan bahasa yang tepat juga sangat berpengaruh terhadap keberhasilan peserta didik dalam persoalan penjumlahan dan pengurangan bilangan bulat karena dengan bahasa akan mampu memudahkan peserta didik untuk menyelesaikannya. Siswa juga harus diperkenankan mempersembahkan ide-ide mereka secara bertutur, menulis, melukis gambar, maupun grafik. Komunikasi bahasa membuka ruang kepada siswa untuk berbincang dan berdiskusi tentang matematika. Jadi jika siswa memiliki kemampuan komunikasi yang baik kemungkinan besar hasil belajar siswa dalam pembelajaran matematika pun akan baik pula (Djamarah, 2002, hal.78-79).

Berdasarkan permasalahan di atas, penulis melakukan observasi dan eksperimen ke salah satu Sekolah Dasar di Kabupaten Banjar yaitu SDN Keraton 3 Martapura. Berdasarkan observasi dan eksperimen yang dilaksanakan di SD tersebut, penulis mencoba meneliti pembelajaran Matematika di Kelas V SDN 
Keraton 3 Martapura dengan judul "Peranan Komunikasi Bahasa dalam Pembelajaran Matematika pada Siswa Kelas V SDN Keraton 3 Martapura"

\section{Metode Penelitian}

Tujuan yang ingin dicapai dalam penelitian ini adalah untuk mengetahui apakah hasil belajar dengan komunikasi bahasa dalam menyelesaikan persoalan penjumlahan dan pengurangan bilangan bulat lebih efektif daripada menggunakan pembelajaran konvensional biasa.

Jenis penelitian yang digunakan adalah penelitian lapangan bersifat eksperimen untuk meneliti pembelajaran Matematika di SDN Keraton 3 Martapura ditinjau dari segi bahasa untuk meningkatkan hasil belajar siswa agar lebih baik lagi. Pendekatan yang digunakan dalam penelitian ini adalah pendekatan kualitatif, karena data yang dihasilkan berupa dokumen pribadi, catatan lapangan, ucapan dan tindakan responden, dokumen dan lainlain yang disajikan dalam bentuk kata-kata.

Penelitian ini dilakukan di SDN

Keraton 3 Martapura yang merupakan salah satu Sekolah Dasar di Kabupaten Banjar. Subjek penelitian ini adalah guru kelas V SDN Keraton 3 Martapura. Objek dari penelitian ini adalah pembelajaran Matematika ditinjau dari Penggunaan Bahasa yang Efektif yang digunakan dalam pembelajaran tersebut. Sampel yang digunakan adalah siswa kelas $\mathrm{V}$ yang terdiri dari 10 orang laki-laki dan 17 orang perempuan.

Teknik pengumpulan data yang digunakan adalah metode wawancara dan metode tes. Metode wawancara digunakan sebagai teknik pengumpulan data apabila ingin dilakukan studi pendahuluan untuk menemukan permasalahan yang harus diteliti. Metode ini digunakan untuk mengetahui metode apa yang biasanya dipakai oleh guru ketika mengajarkan operasi hitung pada bilangan bulat. Metode tes digunakan untuk mendapatkan data tentang hasil belajar peserta didik pada materi operasi penjumlahan dan pengurangan bilangan bulat setelah diberikan materi. Jenis tes yang digunakan adalah tes objektif.

Instrumen yang digunakan dalam penelitian ini adalah tes. Tes yang digunakan secara khusus adalah jenis tes prestasi/ achievement test. Tes prestasi diberikan setelah objek yang dimaksud mempelajari hal-hal yang sesuai dan yang akan diteskan (Arikunto, 2006, hal.150151).

Prosedur dalam penelitian ini adalah dengan menyusun perangkat tes yang disesuaikan dengan Kurikulum Tingkat Satuan Pendidikan(KTSP). Pada perangkat tes penelitian yang akan diujikan adalah materi operasi penjumlahan dan pengurangan bilangan bulat kelas V semester II tahun pelajaran 2015/2016. Dalam penelitian ini tipe soal yang digunakan adalah soal objektif dengan bentuk pilihan ganda yang memiliki empat alternatif jawaban dan hanya satu jawaban yang benar. Setelah perangkat tes disusun, kemudian diuji cobakan kepada sejumlah objek tertentu untuk mengetahui tingkat keabsahan, taraf kesukaran, dan daya pembeda soal.

\section{Hasil Penelitian dan Pembahasan}

Penelitian Tammi (2010) yang berjudul "Pengaruh Kemampuan Komunikasi Matematika terhadap Hasil Belajar Matematika" menemukan bahwa 
pada kelompok siswa yang memiliki kemampuan komunikasi tinggi memberikan hasil belajar yang tinggi pula. Sebaliknya, pada kelompok siswa yang memiliki kemampuan komunikasi rendah memberikan hasil belajar yang rendah pula.

Berdasarkan penelitian di lapangan dengan menggunakan teknik pengumpulan data yang telah ditetapkan yaitu wawancara, observasi, dan dokumentasi maka didapatkan data-data pokok maupun data penunjang yang diperlukan yang dideskripsikan pada hasil observasi dan wawancara "Peranan Komunikasi Bahasa dalam Pembelajaran Matematika di Kelas V SDN Keraton 3 Martapura" dapat dilihat dari penyajian data sebagai berikut.

\section{Komunikasi Bahasa}

Bahasa dapat dicirikan sebagai rangkaian bunyi. Dalam hal ini kita mempergunakan bunyi sebagai alat komunikasi. Komunikasi dengan menggunakan bunyi ini disebut sebagai komunikasi verbal. Jadi dengan bahasa bukan saja manusia dapat berpikir secara teratur, namun juga dapat mengomunikasikan papa yang sedang kita pikirkan kepada orang lain.

Menurut (Mulyana, 2007, hal. 69) komunikasi merupakan bentuk pelemparan pesan atau lambang yang mau tidak mau akan menimbulkan pengaruh pada proses umpan balik, sudah membuktikan adanya jaminan bahwa pesan telah sampai pada pendengar. Kemampuan komunikasi seharusnya meliputi berbagai pemikiran, menanyakan pertanyaan, menjelaskan pertanyaan, dan membenarkan ide-ide. Komunikasi harus terintegrasi dengan baik pada lingkungan kelas.

Unsur-unsur komunikasi dalam pembelajaran terdiri dari: guru, siswa, materi pelajaran, tujuan pembelajaran, media, dan evaluasi (Musfiqon, 2012, hal. 15)

Pentingnya kemampuan komunikasi sebagai hasil belajar, tertuang dalam salah satu kompetensi lintas kurikulum yang merupakan bagian dari kurikulum berbasis kompetensi (Ratumanan, 2003, hal.29), yakni siswa menggunakan bahasa untuk memahami, mengembangkan, dan mengomunikasikan gagasan dari informasi, serta untuk berinteraksi dengan orang lain.

Berbahasa dengan jelas artinya juga mengemukakan pendapat atau jalan pikiran secara jelas. Untuk mampu mengomunikasikan pengetahuan atau jalan pikiran yang jelas maka seseorang harus menguasai tata bahasa dengan baik. Penguasaan tata bahasa yang baik merupakan syarat mutlak bagi suatu komunikasi ilmiah yang benar.

Penggunaan bahasa merupakan salah satu upaya yang bisa dilakukan untuk memecahkan persoalan yang tidak bisa dilakukan melalui garis bilangan. Penggunaan bahasa yang tepat sangat berpengaruh terhadap keberhasilan peserta didik dalam persoalan penjumlahan dan pengurangan bilangan bulat karena dengan bahasa akan mampu memudahkan peserta didik untuk menyelesaikannya.

Berdasarkan pendapat di atas disimpulkan bahwa komunikasi bahasa adalah kemampuan untuk mempresentasikan permasalahan atau ide dalam matematika dengan menggunakan benda nyata, gambar, grafik, atau tabel serta dapat menggunakan simbol matematika.

\section{Logika Bahasa}

Terdapat beberapa macam cara penarikan kesimpulan, namun untuk sesuai dengan tujuan yang memusatkan diri kepada penalaran ilmiah, kita akan melakukan 
penelaahan yang saksama terhadap dua jenis cara penarikan kesimpulan, yakni logika induktif dan logika deduktif.

Major (2006) menyatakan dalam pembelajaran dengan pendekatan deduktif dimulai dengan menyajikan generalisasi atau konsep. Dikembangkan melalui kekuatan argumen logika. Contoh urutan pembelajaran: definisi disampaikan, dan memberi contoh, dan beberapa tugas mirip contoh dikerjakan siswa dengan maksud untuk menguji pemahaman siswa tentang definisi yang disampaikan.

Penalaran deduktif adalah kegiatan berpikir sebaliknya dari penalaran induktif. Deduktif adalah cara berpikir di mana dari pernyataan yang bersifat umum ditarik kesimpulan yang bersifat khusus. Penarikan kesimpulan secara deduktif biasanya mempergunakan pola berpikir silogisme. Silogisme disusun dari dua buah pernyataan dan sebuah kesimpulan. Pernyataan yang mendukung silogisme disebut premis yang kemudian dapat dibedakan menjadi mayor dan minor.

Major (2006) menyarankan dalam pembelajaran dengan pendekatan deduktif: mulailah dengan menyatakan generalisasi secara jelas kemudian tulis definisi di papan tulis, jelaskan istilah-istilah dalam definisi, secara hati-hati tekankan hubungan sifat dalam generalisasi, ilustrasikan dengan contoh, dan berilah kesempatan siswa memberikan atau mengerjakan contoh berikutnya.

Alternatif pendekatan pembelajaran lainnya selain menggunakan logika deduktif adakah dengan logika induktif. Beberapa contoh pembelajaran dengan pendekatan induktif misalnya pembelajaran inquiry, pembelajaran berbasis masalah, pembelajaran berbasis proyek, dan lain-lain. Pembelajaran dengan logika induktif dimulai dengan melakukan pengamatan terhadap hal-hal khusus dan menginterpretasikannya, menganalisis kasus, atau memberi masalah kontekstual, peserta didik dibimbing memahami konsep, aturan, dan prosedur berdasarkan pengamatan siswa itu sendiri.

Induktif merupakan cara berpikir di mana ditarik kesimpulan yang bersifat umum dari berbagai kasus yang bersifat khusus. Penalaran induktif dimulai dengan mengemukakan pernyataan yang mempunyai ruang lingkup yang khas dan terbatas dalam menyusun argumentasi yang diakhiri dengan pernyataan yang bersifat umum.

Major (2006) berpendapat bahwa pembelajaran dengan logika induktif efektif untuk mengajarkan konsep atau generalisasi. Pembelajaran diawali dengan memberikan contoh atau kasus khusus menuju konsep atau generalisasi. Peserta didik melakukan sejumlah pengamatan yang kemudian membangun dalam suatu konsep atau generalisasi. Peserta didik tidak harus memiliki pengetahuan utama berupa abstraksi, tetapi sampai pada abstraksi tersebut setelah mengamati dan menganalisis apa yang diamati.

\section{Pembelajaran Matematika}

Menurut (Arifin, 2009, hal.12) prestasi belajar merupakan suatu masalah yang bersifat perennial dalam sejarah kehidupan manusia, karena Pembelajaran adalah upaya menciptakan iklim dan pelayanan terhadap kemampuan, potensi, minat, bakat, dan kebutuhan peserta didik yang beragam agar terjadi interaksi optimal antara guru dengan peserta didik serta antara peserta didik dengan peserta didik.

$$
\text { Matematika sebagai ilmu }
$$
pengetahuan murni dengan menggunakan 
angka dan lambang serta hubungan antara bilangan dan prosedur operasional yaitu meliputi penambahan, pengurangan, perkalian, dan pembagian (Fathani, 2009, hal 19). Matematika adalah bahasa yang melambangkan serangkaian makna dari pernyataan yang ingin disampaikan. Lambang-lambang matematika bersifat artifisial, yang baru mempunyai arti setelah sebuah makna diberikan kepadanya. Tanpa itu maka matematika hanya merupakan kumpulan rumus-rumus mati.

Menurut (Soedjadi, 1999, hal. 12) matematika sebagai ilmu pengetahuan murni dengan menggunakan angka dan lambang serta hubungan antar bilangan dan prosedur operasional yaitu meliputi penambahan, pengurangan, perkalian, dan pembagian. Matematika dipandang sebagai cara bernalar karena memuat cara pembuatan yang sahih, rumus atau aturan yang umum atau sifat penalaran matematika yang sistematis. Maka matematika terbentuk sebagai hasil pemikiran manusia yang berhubungan dengan ide, proses, dan penalaran. Matematika berguna untuk melatih daya pikir seseorang yang membuatnya kreatif dalam memecahkan masalah-masalah. Matematika secara tidak langsung menjadi tujuan dan bukan alat itu sendiri karena cabang ilmu pengetahuan lain menggunakan dan juga tergantung terhadap matematika.

Belajar matematika adalah belajar tentang konsep dan struktur matematika yang terdapat dalam materi yang dipelajari serta menjelaskan hubungan antara konsep dan struktur itu. Matematika dapat membantu bidang studi antara lain sebagai alat seperti fisika, kimia, statistika, geografi, dan lain-lain. Matematika berguna sebagai penunjang pemakaian alat-alat canggih dan matematika diajarkan untuk terpeliharanya matematika itu sendiri.

\section{Hasil Belajar}

Menurut (Nana Sudjana,1999 hal.

12) "Hasil belajar merupakan kemampuankemampuan yang dimiliki peserta didik setelah ia menerima pengalaman belajar". Kemampuan peserta didik dalam proses belajar oleh Benyamin Bloom diklasifikasikan secara garis besar menjadi tiga ranah sebagai berikut:

1. Ranah kognitif, ranah kognitif berkenaan dengan sikap hasil belajar intelektual yang terdiri dari enam aspek, yang meliputi pengetahuan, pemahaman, penerapan, analisis, sintetis, dan evaluasi.

2. Ranah afektif, berkenaan dengan sikap yang terdiri dari lima aspek, yaitu penerimaan, jawaban atas reaksi, penilaian, organisasi, dan internalisasi.

3. Ranah psikomotorik, berkenaan dengan keterampilan. (Catharina, Tri Anni, 2005,hal.7-10)

Dari uraian di atas dapat disimpulkan bahwa hasil belajar adalah nilai yang dicapai seseorang dengan kemampuan maksimal. Hasil belajar merupakan hal yang penting yang akan dijadikan sebagai tolak ukur keberhasilan peserta didik dalam belajar dan sejauh mana sistem pembelajaran yang diberikan guru berhasil/tidak.

\section{Pembahasan}

Matematika merupakan pelajaran yang dirasa sulit oleh para siswa pada umumnya di sekolah. Di sini tim peneliti mencoba menggali keluhan siswa dari aspek bahasa. Hal ini sangat penting dikarenakan bahasa merupakan bahasa merupakan sumber awal dari kesulitan siswa. Bahasa merupakan alat komunikasi antara dua pihak atau lebih untuk dapat memahami apa 
maksud dari isi pembicaraan yang disampaikan. Oleh karena itu bahasa merupakan kunci keberhasilan untuk dapat memahami matematika ini.

Matematika sebagai ilmu pengetahuan murni dengan menggunakan aneka angka dan lambang serta hubungan bilangan dan prosedur operasional yaitu meliputi pengurangan, penambahan, perkalian, dan pembagian, Menurut Sujono dalam (Abdul Halim Fathani, 2009, hal.19).

Bahasa dan matematika merupakan dua cabang ilmu yang memiliki ruang lingkup keilmuan yang berbeda. Oleh karena itu, tim peneliti mencoba mengungkap kenyataan mengenai bahasa dan matematika ini mempunyai paduan yang dapat disatukan sehingga menjadi suatu paduan yang dapat membantu pembelajaran bagi peserta didik kelas V di SDN Keraton 3 Martapura. Dalam proses pembelajaran matematika, penyampaian materi dengan menggunakan bahasa dalam matematika dapat digunakan secara penalaran deduktif dan induktif atau pembelajaran deduktif dan induktif matematika.

Hasil belajar yang dimaksud dalam penelitian ini adalah indikator keefektifan yang meliputi ranah kognitif pada materi operasi penjumlahan dan pengurangan bilangan bulat. Sehingga melalui evaluasi dapat diperoleh informasi mengenai sejauh mana keberhasilan peserta didik menyerap materi yang disampaikan. Salah satu bentuk evaluasi adalah tes. Dalam penelitian ini, hasil belajar yang dimaksud ialah berupa nilai yang diperoleh peserta didik setelah belajar operasi penjumlahan dan pengurangan pada bilangan bulat.

Sasaran dari penelitian ini adalah materi bilangan bulat, khususnya pada operasi penjumlahan dan pengurangannya. Pada bilangan bulat terdapat dua simbol utama yaitu (+) dan (-)` pemaknaan suatu simbol dalam matematika dikaitkan dengan konteks tertentu yang dibawakan. Dalam materi bilangan bulat, simbol (+) yang diikuti dengan angka dimaknai sebagai bilangan positif, sedangkan simbol (-) yang diikuti dengan angka dimaknai dengan bilangan negatif. Namun, peserta didik merasa kesulitan ketika berhadapan dengan bilangan bulat $(+)$ dan (-) yang dioperasikan melalui penjumlahan dan pengurangan. Karena operasi pada bilangan bulat mempertemukan dua bilangan yang berbeda jenisnya.

Untuk mengatasi kesulitan menghadapi bilangan bulat (+) dan (-) dapat digunakan menggunakan garis bilangan. Akan tetapi, ketika garis bilangan melebihi angka sepuluh itu akan menjadi garis yang panjang sehingga akan mengakibatkan ketidak efektifan garis bilangan.

Untuk soal sederhana $-8+10$, atau 10+(-12), masih bisa dipahami dengan menggunakan garis bilangan. Tetapi garis bilangan tidak banyak membantu apabila 160+(-391) atau 80+ (-150). Sangat sulit ketika menggunakan garis bilangan yang lebih dari sepuluh. Mungkin dapat digunakan garis bilangan yang sangat panjang. Tetapi waktu mereka akan habis untuk membuat garis bilangan yang sangat panjang.

Solusinya dapat diistilahkan bilangan positif sebagai kebaikan dan bilangan negatif sebagai dosa.

Jika seseorang dalam hidupnya selalu melakukan dosa 391 kali dan melakukan kebaikan sebanyak 160 kali, berarti orang itu masih memiliki 231 kali dosa $(160+(-391)$. Alangkah meruginya orang itu.

Berkaca dari pernyataan di atas, penggunaan bahasa merupakan salah satu upaya yang bisa dilakukan untuk memecahkan persoalan yang tidak bisa 
dilakukan melalui garis bilangan. Penggunaan bahasa yang tepat sangat berpengaruh terhadap keberhasilan peserta didik dalam persoalan penjumlahan dan pengurangan bilangan bulat karena dengan bahasa akan mampu memudahkan peserta didik untuk menyelesaikannya.

Maka dari itu, guru memberikan solusi berupa penggunaan bahasa untuk memberikan makna lain pada operasi penjumlahan dan pengurangan bilangan bulat sehingga peserta didik dapat menyerap makna dari simbol tersebut.

Operasi penjumlahan dan pengurangan sejak dahulu dimisalkan dengan utang-piutang atau pinjam meminjam. Penggunaan bahasa hutang piutang ini sejatinya kurang mendidik karena tidak membawa pesan positif, apalagi penggunaan bahasa ini mereka ajarkan kepada adik mereka atau orang lain. Kita dapat menggunakan logika bahasa yang membuat anak lebih mudah dalam memecahkan soal-soal bilangan bulat baik (+) maupun (-).

Matematika mempunyai bahasa dan aturan yang terdefinisi dengan baik, penalaran yang jelas dan sistematik, dan struktur yang sangat kuat. Dengan berbagai keunggulan in, matematika digunakan sebagai suatu cara pendekatan dalam mempelajari ilmu pengetahuan dan teknologi, dan dalam menyelesaikan masalah yang rumit. Unsur utama dalam dalam pekerjaan matematika adalah penalaran deduktif yang bekerja dengan berbagai asumsi, tidak dengan pengamatan.

Pembelajaran deduktif ini sangat erat kaitannya dengan tingkat pengetahuan karena dipengaruhi oleh patokan berpikir siswa. Hal ini paling efektif dilakukan kepada siswa yang belum mengenal apapun tentang beberapa kajian matematika. Logika bahasa dapat digunakan dalam menjelaskan suatu permasalahan matematika diiringi dengan dasar pemikiran yang sama. Untuk itu, diadakan terlebih dahulu apersepsi.

Perhatikan tujuh perintah berikut:

1. Pilih suatu bilangan sembarang( bilangan negatif

2. Tambahkan 2

3. Kalikan 4

4. Kurangi dengan 4

5. Bagi dengan 2

6. Kurangi dengan bilangan yang dipilih pada langkah 1

7. Sebutkan hasilnya

Akan lebih baik daripada seperti ini: $(-7)+2 X 4-$ $4: 2-(-7)=$

Pembelajaran dengan pendekatan induktif dimulai dengan melakukan pengamatan terhadap hal-hal khusus, yaitu mendahulukan perkalian atau pembagian terlebih dahulu, menganalisis kasus, atau memberi masalah kontekstual, siswa dibimbing memahami konsep, aturan, dan prosedur berdasar pengamatan siswa sendiri.

Semua makhluk hidup mempunyai dosa sebanyak 190 dan kebaikan sebanyak 105 (premis mayor)

Si Jova adalah seorang makhluk hidup (premis minor)

Jadi, si Jova memiliki dosa 190 dan kebaikan 105 (kesimpulan)

Daripada dengan bentuk matematika yang membuat lelah peserta didik SD apabila melihat soal-soal yang semua bentuknya adalah angka : $n=105+(-190)$

Kesimpulan yang dapat diambil bahwa si Jova memiliki dosa dan kebaikan menurut penalaran deduktif. Sebab kesimpulan ini ditarik secara logis dari dua premis yang mendukungnya. Jadi sisa dosa yang dimiliki Jova adalah masih 85 dosa yang harus ditutupi dengan kebaikan.

Berdasarkan hasil penelitian maka terbukti bahwa terdapat pengaruh positif 
kemampuan komunikasi bahasa dalam matematika terhadap prestasi belajar matematika. Hal ini menunjukkan bahwa prestasi belajar siswa akan semakin baik jika kemampuan komunikasi bahasa dalam matematika lebih ditingkatkan lagi. Maka dalam penelitian ini guru kelas khususnya pembelajaran matematika harus menciptakan metode belajar yang baik agar dapat dilakukan pemilahan dan perlakuan yang tepat dalam proses belajar mengajar pada khususnya tentang materi bilangan bulat. Hasil penelitian menunjukkan bahwa secara umum teknik guru dalam meningkatkan kemampuan komunikasi bahasa dalam pembelajaran matematika peserta didik memberikan kontribusi perolehan prestasi belajar matematika yang lebih baik.

Berdasarkan analisis yang dilakukan tentang komunikasi bahasa dalam pembelajaran matematika tampak bahwa siswa dapat menyatakan suatu masalah matematika dengan menggunakan bahasa sendiri atau menerjemahkan ke dalam model matematika dan mengalami proses belajar yang positif. Ini terlihat dari siswa yang berusaha saat menemui kesulitan dalam menyusun atau menjawab soal meningkat $6,59 \%$ dari $17,8 \%$ menjadi $24,39 \%$, yang meminta bantuan teman juga mengalami peningkatan dari $17,08 \%$ menjadi $41,4 \%$. Hal ini menunjukkan bahwa siswa tidak tergantung kepada guru, justru dapat berinteraksi antara siswa yang satu dengan yang lainnya.

Hasil yang diperoleh dari beberapa temuan ini menunjukkan bahwa kemampuan komunikasi bahasa dalam pembelajaran matematika memberikan kesempatan kepada siswa untuk mengembangkan kemampuan mengomunikasikan ide melalui bahasa dan simbol untuk memecahkan suatu masalah tertentu dalam pembelajaran matematika. Berdasarkan temuan ini terungkap bahwa kemampuan komunikasi bahasa dalam pembelajaran matematika dapat meningkatkan prestasi belajar matematika peserta didik.

\section{Simpulan dan Saran}

\section{Simpulan}

Berdasarkan hasil penelitian ini menunjukkan bahwa pengaruh yang positif dan signifikan antara kemampuan komunikasi bahasa dengan pembelajaran matematika siswa. Dengan semakin tinggi pula prestasi belajar matematika siswa kelas V SDN Keraton 3 Martapura. Terjadi peningkatan yang signifikan ketika peserta didik menjawab soal.

Untuk melakukan kegiatan ilmiah secara baik dan benar dalam mengembangkan ilmu pengetahuan diperlukan sarana berpikir, yaitu bahasa, logika, matematika, dan statistika. Bahasa atau logika dalam pembelajaran matematika dapat digunakan dengan berbagai cara penyampaian yaitu deduktif dan induktif. Deduktif dan induktif dapat digunakan sesuai dengan tujuan pembelajaran agar dapat dimengerti oleh peserta didik. Namun, hal yang terpenting dari itu adalah bahasa matematika dapat juga diterapkan dengan inovasi baru agar dimengerti oleh siswa pada saat pembelajaran berlangsung.

\section{Saran}

Bahasa diperlukan saat pembelajaran matematika ini dengan inovasi baru sehingga siswa tidak mengalami kejenuhan. Bahasa merupakan kunci penting dari pemahaman siswa terhadap matematika, perlu adanya keluwesan guru 
menyampaikan bahasa dalam pembelajaran matematika ini dengan bahasa kekinian saat ini. Bahasa kekinian adalah bahasa yang digunakan dalam kehidupan sehari-hari. Hal yang seperti itu dapat menjadikan suasana yang dibawa oleh guru menjadi menarik dan akan membawa motivasi tersendiri bagi peserta didik.

Berdasarkan hasil penelitian ini maka saran dan harapan yang bisa peneliti sampaikan yaitu agar guru dapat lebih mengembangkan profesionalisme dalam mengajar sebagai upaya mewujudkan pembelajaran yang berpusat pada peserta didik dalam Kegiatan Belajar Mengajar sehingga berpengaruh pada peningkatan kemampuan komunikasi bahasa dalam pembelajaran matematika pada peserta didik.

\section{Daftar Pustaka}

Djamarah, Syaiful Bahri dan Azwan Zain. (2002). Strategi Belajar Mengajar. Jakarta: Rineka Cipta.

Fathani, Abdul Halim. (2009). Matematika: Hakikat dan Logika. Jogjakarta: ArRuzz Media.

Handoyo, Bekti Hermawan. (2007). Matematika Akhlak: Keajaiban Bahasa untuk Mendidik Akhlak Mulia. Jakarta: Kawan Pustaka.

Major, F.T. (2006) The Squencing of Content Inductive and Deductive Approach.http://educ.hku.hk/download 10 April 2016.

Mulyana, D. (2007). Ilmu Komunikasi dan Pengantar. Bandung: PT Remaja Rosdakarya.
Musfiqon, H.M. (2012). Pengembangan Media dan Sumber Pembelajaran. Jakarta: PT, Prestasi Pustakaraya.

Slameto. (2003). Belajar dan Faktor-Faktor yang Mempengaruhinya. Cetakan V. Jakarta: PT.Rineka Cipta.

Syaban, M. (2009). Menumbuhkembangkan Daya Matematis Siswa. http://educare.efkipunla.net. Diakses 10 April 2017.

Sudjana, Nana. (2008). Penilaian Hasil Proses Belajar Mengajar. Bandung: PT.Remaja Rosdakarya.

Tim Supermath. (2007) 18 Strategi Pemecahan Masalah Matematika SD. Jakarta: Literatur Media Sukses.

Tirtahardja, U. (2005). Pengantar Pendidikan. Cetakan II. Jakarta: PT. Rineka Cipta. 